\title{
Alcoholic liver disease and changes in bone mineral density
}

\author{
Germán López-Larramona ${ }^{1}$, Alfredo J. Lucendo ${ }^{2}$ and Laura González-Delgado ${ }^{3}$ \\ Departments of ${ }^{1}$ Internal Medicine and ${ }^{2}$ Gastroenterology. Hospital General de Tomelloso. ${ }^{3}$ Primary Care Division. \\ Tomelloso Primary Care Area. Tomelloso, Ciudad Real. Spain
}

\begin{abstract}
Osteoporosis and osteopenia are alterations in bone mineral density (BMD) that frequently occur in the context of chronic liver disease (CLD). These alterations have been studied predominantly in chronic cholestatic disease and cirrhosis of the liver. Alcohol consumption is an independent risk factor for the onset of osteoporosis, whose estimated prevalence in patients with alcoholic liver disease (ALD) ranges between $5 \%$ and $40 \%$. The loss of BMD in ALD is the result of an imbalance between bone formation and resorption. Its pathogenesis is multifactorial and includes the toxic effects of alcohol on bone and endocrine and nutritional disorders secondary to alcoholism and a deficiency of osteocalcin, vitamin $\mathrm{D}$ and insulin growth factor- 1 . The diagnosis of BMD alterations in ALD is based on its measurement using bone densitometry. Treatment includes smoking and alcohol cessation and general measures such as changes in nutrition and exercise. Calcium and vitamin D supplements are recommended in all patients with ALD and osteoporosis. Bisphosphonates are the most commonly prescribed drugs for the specific treatment of this condition. Alternatives include raloxifene, hormone replacement therapy and calcitonin.

This review will address the most important aspects involved in the clinical management of abnormal BMD in the context of ALD, including its prevalence, pathogenesis and diagnosis. We will also review the treatment of osteoporosis in CLD in general, focusing on specific aspects related to bone loss in ALD.
\end{abstract}

Key words: Osteopenia. Osteoporosis. Bone mineral density. Alcoholic liver disease. Chronic liver disease. Alcohol.

Received: 11-03-2013

Accepted: 03-06-2013

Correspondence: Germán López Larramona. Department of Internal Medicine. Hospital General de Tomelloso. Vereda de Socuéllamos, s/n. 13700 Tomelloso, Ciudad Real. Spain

e-mail: germl12003@yahoo.es

\section{ABBREVIATIONS}

ALD: Alcoholic liver disease.

BMD: Bone mineral density.

BMI: Body mass index.

CLD: Chronic liver disease.

$\mathrm{HCV}$ : Hepatitis $\mathrm{C}$ virus.

IGF-1: Insulin growth factor-1.

IL-1 $\beta$ : Interleukin 1-beta.

IL-6: Interleukin-6.

OC: Osteocalcin.

OLT: Orthotopic liver transplantation.

OPG: Osteoprotegerin.

PBC: Primary biliary cirrhosis.

PTH: Parathyroid hormone.

RANK: Receptor activator of nuclear factor-KappaB.

RANKL: Receptor activator of NF-KappaB ligand.

SHBG: Sex hormone-binding globulin.

TNF- $\alpha$ : Tumour necrosis factor-alpha.

VDR: Vitamin D receptor.

\section{INTRODUCTION}

Chronic liver disease (CLD) is a major cause of morbidity and mortality worldwide. It involves haemodynamic and metabolic complications, such as liver failure, portal hypertension, encephalopathy, ascites, hepatorenal syndrome and gastrointestinal bleeding from oesophageal varices (1). CLD is also a risk factor for the development of osteoporosis and bone fractures. The term "hepatic

López-Larramona G, Lucendo AJ, González-Delgado L. Alcoholic liver disease and changes in bone mineral density. Rev Esp Enferm Dig 2013;105:609-621. 
osteodystrophy" is used to refer generally to various bone disorders that develop in the context of chronic liver disease. This general term encompasses osteopenia, osteoporosis and osteomalacia. The first two are characterised by a loss of mineral density and a deterioration of bone microarchitecture, which predisposes to fragility fractures. However, osteomalacia, which is characterised by poor bone mineralization, is very seldom observed in CLD (2). BMD loss and the consequent increase in fracture risk have been described mainly in chronic cholestatic diseases - primary biliary cirrhosis (PBC) and primary sclerosing cholangitis- and in advanced stages of liver cirrhosis (3). However, an increasing number of observations have been published in recent years on the topic of BMD alterations in the context of liver diseases of other aetiologies and in the non-cirrhotic stage, such as viral hepatitis (4), non-alcoholic fatty liver disease (5), alcoholic liver disease (6) (ALD) and haemochromatosis $(7,8)$.

ALD is a leading cause of liver-related death in developed countries (9), and covers a broad spectrum of clinical and laboratory manifestations, ranging from asymptomatic fatty liver to alcoholic hepatitis or cirrhosis with liver failure, jaundice, coagulation disorders and encephalopathy. The American College of Gastroenterology has drawn up some guidelines with recommendations for the diagnosis of ALD, which give special importance to medical history, clinical signs and laboratory findings (10). It is important to be familiar with the risk factors that promote the development of advanced liver failure. These notably include the high prevalence of hepatitis $\mathrm{C}$ virus (HCV) infection reported among alcoholics (between $25 \%$ and $65 \%$ ), which favours the progression of liver fibrosis and associated comorbidity (11).

Alcohol consumption is a risk factor for the onset of osteoporosis and has been associated with an increased risk of osteoporotic bone fracture in men, irrespective of the presence of cirrhosis or hypogonadism (12-14). A study that included 96 male alcoholics detected radiological osteoporosis in $47 \%$ of the men, most of them aged between 46 and 62 years (15). Another study that compared 39 male alcoholics with 19 healthy non-drinkers reported osteopenia in $23 \%$ of those who drank $>100 \mathrm{~g}$ of alcohol/day for more than 10 years. In addition, the group of alcoholics exhibited significantly lower levels of bone Gla protein, and their bone mineral density (BMD) correlated inversely with cumulative alcohol intake (16). The presence of BMD abnormalities among alcoholic patients has been studied in different papers, with mixed results: While some studies found no significant changes in bone mass $(17,18)$, other authors have reported a decrease in BMD among individuals with active alcoholism $(19,20)$.

The prevalence of abnormal BMD in patients with ALD varies in the series published, which include cirrhotic patients with chronic liver disease of different aetiologies. In these series, the prevalence of osteoporosis was $41 \%$, while that of osteopenia ranged between $26 \%$ and
$47 \%$ (21-30) (Table I). Specific studies have been conducted in alcoholic subjects with associated liver disease in very uneven proportions (cirrhosis between $0 \%$ and $52 \%$ ), where the incidence of osteoporosis was $11-22 \%$ while osteopenia affected $100 \%$ of the patients $(6,19,20,31-33)$ (Table II). Alcohol-induced liver disease encompasses a wide spectrum of illnesses, and consequently it is difficult to specify an exact prevalence for each stage. According to what is described in CLD of other aetiologies, the highest incidence of BMD loss is seen in cases of cirrhosis. Particular attention should therefore be paid to the risk of osteopenia and osteoporosis in patients with established alcoholic cirrhosis. The series published report predominance in men, although male sex is also the most prevalent among alcoholics in the general population. Risk factors involved in BMD loss vary from one study to another and are summarised in tables I and II.

\section{AETIOPATHOGENESIS}

BMD loss in chronic alcohol-induced liver disease is multifactorial and is largely determined by a defect in bone tissue formation. Most studies on osteoporosis in CLD describe deficient osteoblast function as the predominant pathogenic mechanism, as has been shown in histomorphometric studies of bone biopsies from individuals with PBC $(34,35)$. Deficient osteoblast function is also reflected by the low levels of osteocalcin (OC) and IGF-1 (insulin growth factor-1) deficiency observed in CLD of different aetiologies (36). However, an increase in osteoclast activity could also influence the development of bone disease, as showed by histomorphometric tests conducted in the context of chronic cholestatic disease $(37,38)$. In addition, both the serum and the bilirubin of jaundiced patients with PBC and advanced-stage CLD increase the gene expression of factors linked to osteoclastogenesis in human osteoblast and SAOS-2 osteosarcoma cell cultures (39). Chronic alcohol consumption also promotes osteoclast activity in murine models through interleukin (IL)-6-mediated induction of the RANKL (receptor activator of NF-KappaB ligand) system (40).

From an aetiopathogenic point of view, there are three main groups of risk factors for the development of alterations in bone mass in patients with alcoholic liver disease:

1. Ethanol has a direct dose-dependent toxic effect on osteoblasts, which inhibits bone formation and turnover (31). The negative effect of alcohol on the proliferation of osteoblast cultures has been demonstrated both in healthy subjects and in animal models (41). A deterioration in the biomechanical properties of bone, a reduction in femoral cortical BMD and an imbalance between bone formation and resorption could all be observed in these models (42). In a group of 32 alcoholics, the prevalence of osteoporosis was $34 \%$, with a significant reduction in lumbar and femoral BMD, and decreased bone formation associated 
Table I. Published studies of patients with chronic liver disease of mixed aetiology, including alcoholic liver disease

\begin{tabular}{|c|c|c|c|c|c|c|c|}
\hline $\begin{array}{l}\text { Author } \\
\text { and year }\end{array}$ & $\begin{array}{l}\text { Aetiology } \\
\text { (\% alcoholic) }\end{array}$ & $\begin{array}{l}n \\
\text { (no. men) }\end{array}$ & $\begin{array}{l}\text { Cirrhosis } \\
(\% \text { Child } A / B / C)\end{array}$ & Study type & $\begin{array}{l}\text { BMD (bone mineral } \\
\text { density) }\end{array}$ & $\begin{array}{l}\text { Differences } \\
\text { between } \\
\text { aetiologies }\end{array}$ & Risk factors involved \\
\hline $\begin{array}{l}\text { Crawford, } \\
2003(21)\end{array}$ & $\begin{array}{l}\text { Viral } \\
\text { ALD (16.8 \%) } \\
\text { Chronic } \\
\text { cholestasis } \\
\text { Other }^{\text {a }}\end{array}$ & $\begin{array}{l}113 \\
(81)\end{array}$ & $\begin{array}{l}100 \% \\
(25.6 / 43.3 / 30.9)\end{array}$ & $\begin{array}{l}\text { Unchecked } \\
\text { description }\end{array}$ & $\begin{array}{l}\text { Osteopenia: } 40 \% \\
\text { Osteoporosis: } 31 \% \\
\text { M, } 22 \% \text { W }\end{array}$ & No & $\begin{array}{l}\text { Age }(\mathrm{W}) \\
\text { Testosterone levels (M) } \\
\text { Low levels of } 250 \mathrm{HD} 3- \\
\text { Loss of BMD FN }\end{array}$ \\
\hline $\begin{array}{l}\text { Carey, } \\
2003(22)\end{array}$ & $\begin{array}{l}\text { HCV } \\
\text { ALD }(31.8 \%) \\
\text { HCV+ALD } \\
(35.2 \%)\end{array}$ & $\begin{array}{l}207 \\
(131)\end{array}$ & $100 \%$ & $\begin{array}{l}\text { Unchecked } \\
\text { description }\end{array}$ & $\begin{array}{l}\text { Osteopenia: } 26.7 \% \\
\text { Osteoporosis } 18.3 \% \\
\text { T-score L: }-0.87+ \\
1.61^{*}\end{array}$ & $\begin{array}{l}\text { Osteoporosis } \\
\text { in HCV } 28.1 \% \\
\text { vs. } 13.8 \% \text { in } \\
\text { HCV + ALD ( } p \\
=0.02)\end{array}$ & $\begin{array}{l}\text { T-score associated with } \\
\text { risk of fracture }\end{array}$ \\
\hline $\begin{array}{l}\text { Sokhi, } \\
2004 \text { (23) }\end{array}$ & $\begin{array}{l}\text { HCV } \\
\text { ALD (16.3\%) } \\
\text { Cholestatic } \\
\text { Other }^{b}\end{array}$ & $\begin{array}{l}104 \\
(54)\end{array}$ & $\begin{array}{l}100 \% \\
(-/ 49.1 / 50.9)\end{array}$ & $\begin{array}{l}\text { Unchecked } \\
\text { description }\end{array}$ & $\begin{array}{l}\text { Osteopenia } 34.6 \% \\
\text { Osteoporosis } 11.5 \%\end{array}$ & No & $\begin{array}{l}\text { Female sex } \\
\text { T-score lower in Child C } \\
\text { vs. Child B }(p<0.0001)\end{array}$ \\
\hline $\begin{array}{l}\text { George, } \\
2009(24)\end{array}$ & $\begin{array}{l}\text { Viral } \\
\text { ALD (51.3 \%) }\end{array}$ & $72(63)$ & $\begin{array}{l}100 \% \\
(31.9 / 54.1 / 13.8)\end{array}$ & $\begin{array}{l}\text { Unchecked } \\
\text { description }\end{array}$ & $\begin{array}{l}\text { Low BMD (Z-score < } \\
2.0): 68 \% \text { overall; } \\
56.7 \% \text { ALD }\end{array}$ & NS & $\begin{array}{l}\text { Low physical activity } \\
\text { Low sun exposure } \\
\text { Low lean body mass } \\
\text { Low BMD associated } \\
\text { with low levels of IGF-1 } \\
(p<0.05)\end{array}$ \\
\hline $\begin{array}{l}\text { Loria, } \\
2010 \text { (25) }\end{array}$ & $\begin{array}{l}\text { Viral } \\
\text { ALD }(28 \%) \\
\text { Viral + ALD } \\
(11 \%)\end{array}$ & $35(27)$ & $\begin{array}{l}100 \% \\
(20 / 37 / 43)\end{array}$ & $\begin{array}{l}\text { Unchecked } \\
\text { description }\end{array}$ & $\begin{array}{l}\text { Osteopenia } 26 \% \\
\text { Osteoporosis } 14 \%\end{array}$ & No & Cirrhosis \\
\hline $\begin{array}{l}\text { Mitchell, } \\
2011(26)\end{array}$ & $\begin{array}{l}\text { Viral } \\
\text { ALD (17 \%) } \\
\text { Chronic } \\
\text { cholestasis } \\
\text { Other }\end{array}$ & $\begin{array}{l}117 \\
(74)\end{array}$ & $100 \%$ & $\begin{array}{l}\text { Unchecked } \\
\text { description }\end{array}$ & $\begin{array}{l}\text { Osteopenia } 47 \% \\
\text { Osteoporosis } 21.4 \% \\
\text { T-score L }-1.51+ \\
1.35^{\star}\end{array}$ & No & $\begin{array}{l}\text { Low BMI and low levels } \\
\text { of IGF-1 associated with } \\
\text { low BMD in FN and L. } \\
\text { Low levels of } 250 \mathrm{OHD} 3 \\
\text { associated with low BMD } \\
\text { in FN }\end{array}$ \\
\hline $\begin{array}{l}\text { Mahmoudi, } \\
2011 \text { (27) }\end{array}$ & $\begin{array}{l}\text { Viral } \\
\text { ALD }(28.4 \%)\end{array}$ & $\begin{array}{l}109 \\
(72)\end{array}$ & $\begin{array}{l}100 \% \\
(100 /-/-)\end{array}$ & $\begin{array}{l}\text { Unchecked } \\
\text { description }\end{array}$ & $\begin{array}{l}\text { Osteopenia } 44 \% \\
\text { Osteoporosis } 14.6 \%\end{array}$ & No & Female sex \\
\hline $\begin{array}{l}\text { Wibaux, } \\
2011(28)\end{array}$ & $\begin{array}{l}\text { Viral } \\
\text { ALD }(75.7 \%) \\
\text { Other }^{d}\end{array}$ & $99(70)$ & $100 \%$ & $\begin{array}{l}\text { Unchecked } \\
\text { description }\end{array}$ & $\begin{array}{l}\text { Osteopenia } 35 \% \\
\text { Osteoporosis } 38 \%\end{array}$ & No & $\begin{array}{l}\text { Low BMD associated } \\
\text { with risk of vertebral } \\
\text { fracture } \\
\text { Negative correlation } \\
\text { between bone resorption } \\
\text { markers and lumbar and } \\
\text { hip BMD } \\
\text { Negative correlation } \\
\text { between MELD and hip } \\
\text { BMD }\end{array}$ \\
\hline $\begin{array}{l}\text { Choudhary, } \\
2011(29)\end{array}$ & $\begin{array}{l}\text { Viral } \\
\text { ALD (58.2 \%) }\end{array}$ & $\begin{array}{l}115 \\
(107)\end{array}$ & $100 \%$ & $\begin{array}{l}\text { Unchecked } \\
\text { description }\end{array}$ & $\begin{array}{l}\text { Low BMD } 97 \% \\
\text { alcoholic cirrhosis } \\
\text { Osteopenia } 55.2 \% \text { * } \\
\text { Osteoporosis } 41.7 \%\end{array}$ & No & $\begin{array}{l}\text { Negative correlation of } \\
\text { PTH levels and BMD }\end{array}$ \\
\hline $\begin{array}{l}\text { Alcalde- } \\
\text { Vargas, } \\
2012(30)\end{array}$ & $\begin{array}{l}\text { Viral } \\
\text { ALD (59 \%) } \\
\text { Chronic } \\
\text { cholestasis } \\
\text { Othere }\end{array}$ & $\begin{array}{l}486 \\
(384)\end{array}$ & $\begin{array}{l}100 \% \\
(22 / 51 / 27)\end{array}$ & $\begin{array}{l}\text { Unchecked } \\
\text { description }\end{array}$ & $\begin{array}{l}\text { Osteopenia: L } 40 \% \text {, } \\
\text { FN } 43 \% \\
\text { Osteoporosis: L } \\
23 \% \text {, FN } 5 \%\end{array}$ & No & $\begin{array}{l}\text { Female sex } \\
\text { Low BMl } \\
\text { Nicotine intake }\end{array}$ \\
\hline
\end{tabular}

L: Lumbar; FN: Femoral neck; W: Women; M: Men; HCV: Hepatitis C virus; ALD: Alcoholic liver disease; 25OHD3: 25-hydroxyvitamin D3; MELD: Model for End-Stage Liver Disease; NS: Not specified. ${ }^{a}$ Cryptogenic, autoimmune hepatitis. ${ }^{b} \mathrm{Cryptogenic} \mathrm{cirrhosis,} \mathrm{hereditary} \mathrm{haemochromatosis,} \mathrm{non-alcoholic}$ steatohepatitis, autoimmune hepatitis. CHereditary haemochromatosis, Wilson's disease, alpha 1-antitrypsin deficiency. ${ }^{\mathrm{d} A u t o i m m u n e}$ hepatitis, chronic cholestatic disease. ePrimary and secondary biliary cirrhosis, other unspecified causes. 
Table II. Studies in alcoholic patients with and without liver cirrhosis

\begin{tabular}{|c|c|c|c|c|c|c|c|}
\hline $\begin{array}{l}\text { Author } \\
\text { Year }\end{array}$ & $\begin{array}{l}\text { Alcohol } \\
\text { consumption } \\
\text { g/day }\end{array}$ & $\begin{array}{l}n \text { (no. } \\
\text { ben) }\end{array}$ & $\begin{array}{l}\text { Cirrhosis n/\% } \\
\text { Child (A/B/C) }\end{array}$ & Study type & $\%$ altered $B M D$ & T-score & Main results \\
\hline $\begin{array}{l}\text { Kim, } \\
2003(19)\end{array}$ & $\begin{array}{l}97.7 \text { (range } \\
43-430 \text { ) }\end{array}$ & $\begin{array}{l}18 \\
(18)\end{array}$ & 0 & $\begin{array}{l}\text { Checked } \\
\text { description }\end{array}$ & $\begin{array}{l}\text { Osteopenia } 50 \% \\
\text { Osteoporosis } 22 \%\end{array}$ & $\begin{array}{l}\text { L: } 1.040+0.14 \\
\text { FN: } 0.844+ \\
0.12\end{array}$ & $\begin{array}{l}\text { Relationship between } \\
\text { cumulative amount of } \\
\text { alcohol ingested and } \\
\text { lumbar BMD }\end{array}$ \\
\hline $\begin{array}{l}\text { Malik, } \\
2009(20)\end{array}$ & $\begin{array}{l}\text { Men: } 259.2+ \\
133.2 \\
\text { Women: } 210+ \\
103.2\end{array}$ & $\begin{array}{l}57 \\
(37)\end{array}$ & 0 & $\begin{array}{l}\text { Unchecked } \\
\text { description }\end{array}$ & $\begin{array}{l}\text { Low BMD (Z-score } \\
<2.0) \text { : } \\
24.3 \% \text { men } \\
5 \% \text { women }\end{array}$ & - & $\begin{array}{l}\text { Nutritional factors } \\
\text { Sun exposure }\end{array}$ \\
\hline $\begin{array}{l}\text { González- } \\
\text { Reimers, } \\
2011(6)\end{array}$ & $208+78$ & $\begin{array}{l}124 \\
(124)\end{array}$ & $\begin{array}{l}52 \\
(11.5 / 28.8 / 59.6)\end{array}$ & $\begin{array}{l}\text { Checked } \\
\text { prospective } \\
\text { description }\end{array}$ & $\begin{array}{l}\text { Osteopenia } 100 \% \\
\text { Osteoporosis: } \\
\text { L: } 13.4 \% \\
\text { FN: } 8.9 \%\end{array}$ & $\begin{array}{l}\mathrm{L}:-1.17+1.22 \\
\mathrm{FN}:-1.24+1.38\end{array}$ & $\begin{array}{l}\text { Nutritional factors, } \\
\text { malnutrition } \\
\text { Cirrhosis }\end{array}$ \\
\hline $\begin{array}{l}\text { Alvisa- } \\
\text { Negrín, } \\
2009 \text { (31) }\end{array}$ & $204+82$ & $\begin{array}{l}77 \\
(68)\end{array}$ & 41 & $\begin{array}{l}\text { Checked } \\
\text { description }\end{array}$ & $\begin{array}{l}\text { Osteopenia } 100 \% \\
\text { Osteoporosis } \\
11.7 \%\end{array}$ & $\begin{array}{l}\mathrm{L}:-1.20+1.16 \\
\mathrm{FN}:-1.10+1.28\end{array}$ & $\begin{array}{l}\text { Cumulative amount of } \\
\text { alcohol ingested } \\
\text { Deterioration of } \\
\text { nutritional status }\end{array}$ \\
\hline $\begin{array}{l}\text { González- } \\
\text { Reimers, } \\
2011(32)\end{array}$ & $212+79$ & $\begin{array}{l}90 \\
(90)\end{array}$ & $\begin{array}{l}40 \\
(5.0 / 32.5 / 62.5)\end{array}$ & $\begin{array}{l}\text { Checked } \\
\text { description }\end{array}$ & $\begin{array}{l}\text { Osteoporosis } \\
15.5 \% \text { (L: } 64.2 \%)\end{array}$ & $\begin{array}{l}\mathrm{L}:-1.15+1.18 \\
\mathrm{FN}:-1.05+1.16\end{array}$ & $\begin{array}{l}\text { Cirrhosis: lower } \\
\text { lumbar T-score } \\
\text { Cirrhosis and multiple } \\
\text { fractures: Lower BMD } \\
\text { and lumbar T-score }\end{array}$ \\
\hline $\begin{array}{l}\text { Malik, } \\
2012 \text { (33) }\end{array}$ & - & $\begin{array}{l}53 \\
(53)\end{array}$ & 0 & Description & $\begin{array}{l}\text { Low BMD (Z-score } \\
<2.0) \text { : } \\
\text { L } 15.1 \% \\
\text { FN } 5.7 \%\end{array}$ & - & $\begin{array}{l}\text { Significant increase } \\
\text { in OC (osteocalcin) } \\
\text { levels after } 8 \text { weeks of } \\
\text { abstinence } \\
\text { Positive correlation } \\
\text { physical activity/Z- } \\
\text { score L, FN and total } \\
\text { hip }\end{array}$ \\
\hline
\end{tabular}

L: Lumbar; FN: Femoral neck; BMD: Bone mineral density.

with low levels of GLA protein, which is analogous to osteocalcin (OC) in terms of its bone-forming activity, and whose deficiency reverted with alcohol abstinence (43).

More recent studies have reported increased serum levels of sclerostin in alcoholics; this molecule inhibits the $\mathrm{Wnt} / \beta$-catenin signalling pathway, and thus the differentiation, function and average lifespan of osteoblasts. Levels of sclerostin correlate positively with those of bone resorption markers such as the $\mathrm{N}$-terminal telopeptide, and inversely with osteocalcin concentrations (44).

2. Alcoholism can cause alterations in nutritional status and vitamin $\mathrm{D}$ deficiency: Both factors, together with the loss of muscle mass secondary to alcohol consumption, have been associated with an increased risk of bone fracture (32). Changes in dietary habits, irregular food intake and protein deficiencies also contribute to bone loss (45), and promote low levels of serum calcium, phosphorus and magnesium (46). Intestinal bacterial overgrowth occurs as much in the context of alcoholism as that of liver cirrhosis and contributes to a deterioration of nutritional status by causing a malabsorption syndrome. The overall increase in the intestinal flora and its qualitative alteration promote gastrointestinal and nutrient absorption disorders. These conditions affect the absorption of fat as a result of bile acid deconjugation, which in turn has a negative effect on the absorption of lipids, proteins and carbohydrates (47).

3. Both alcoholism and liver disease per se involve a number of endocrine and metabolic disorders, and promote the release of cytokines with deleterious effects on bone metabolism. Several endocrinologic disorders involved in bone homeostasis, such as hyperparathyroidism, hypogonadism with low concentrations of free testosterone, hypercortisolism and dysregulation of the hypothalamic-pituitary-gonadal axis are present in patients with ALD (19). A deficiency of IGF-1 has been reported in association with liver diseases of various aetiologies, which has a negative impact on mineralization, as osteoblast proliferation and collagen synthesis in the bone matrix thus fail to be stimulated (48). Vitamin D deficiency associated with CLD is multifactorial $(3,49)$ and associated with secondary hyperparathyroidism, increased bone turnover and loss of BMD. Low serum levels of 25-hydroxyvitamin D have been described in patients with alcoholic cirrhosis, with an estimated incidence of $32 \%$ of cases with vitamin D3 
levels below $20 \mathrm{ng} / \mathrm{mL}$ (50). Levels of 25-hydroxyvitamin D continue to decline as cirrhosis progresses (51), but this deficiency rarely gives rise to osteomalacia, as described in some bone morphometric tests in patients with alcoholic cirrhosis (52). Despite this, and although hypovitaminosis is common in CLD, most studies have failed to find a significant correlation between serum vitamin D levels and the onset of osteopenia, suggesting that this vitamin deficiency might contribute scarcely to the pathogenesis of hepatic osteodystrophy (53), as could the function of certain vitamin D receptor gene polymorphisms (54). The damaging effects of certain bile acids on osteoblast viability through their interference with vitamin $\mathrm{D}$ receptor function has also been studied: Lithocholic acid, whose concentration can increase in advanced CLD, interferes with the function of these receptors by affecting the vitamin $\mathrm{D}$ function and inhibiting the expression of pro-osteogenic genes like the one that encodes OC (55).

Vitamin $\mathrm{K}$ is a cofactor in the synthesis of OC by osteoblasts. Treatment with vitamin $\mathrm{K}$ prevented loss of bone mass in a group of women with viral cirrhosis (56), but other studies of patients with PBC failed to show a link between vitamin $\mathrm{K}$ and BMD loss (57).

Hypogonadism is common in alcoholic liver disease and haemochromatosis; this is due to the low level of release of hypothalamic gonadotropin and primary gonadal dysfunction (13). Men with alcoholic cirrhosis have reduced levels of testosterone, which increases the risk of hip fracture (58). Amenorrheic women with ALD also exhibit low serum levels of luteinising hormone (LH), follicle-stimulating hormone (FSH) and oestradiol, which may predispose them to increased bone loss (57).

The RANK/RANKL/OPG system exerts an important modulatory effect on bone turnover. RANK receptor activation by RANKL stimulates osteoclast differentiation from osteoblasts. Conversely, the binding of osteoprotegerin (OPG) to RANKL inhibits osteoclast activation and osteoblast apoptosis, and acts as a protective mechanism for $\operatorname{BMD}(59,60)$. Alcoholics display significantly elevated serum levels of TNF- $\alpha$, IL- $1 \beta$ and IL- 6 , regardless of the stage of liver disease (61). These cytokines are released by the direct effect of ethanol and the liver disease itself (40) and regulate the RANK/OPG system by promoting the production of RANKL and osteoclastogenesis $(62,63)$. Increased serum levels of OPG have also been described in alcoholic patients, which would imply a compensatory mechanism to cope with increased concentrations of proresorptive cytokines (64).

\section{DIAGNOSIS}

CLD, especially in the cirrhotic stage, is a risk factor for the development of osteoporosis and bone fractures. Bone mineral metabolism disorders should always be considered in cirrhotic patients and chronic cholestatic disease, especially PBC (65). The diagnostic approach to patients with ALD and suspected low BMD should consider all existing risk factors for the onset of osteoporosis: Alcohol abuse and daily intake, smoking, body mass index (BMI) $<19 \mathrm{~kg} / \mathrm{m}^{2}$, hypogonadism in men, early menopause (under the age of 45), secondary amenorrhoea for longer than 6 months, family history of fragility fractures and glucocorticoid treatment (doses of prednisone higher than $5 \mathrm{mg}$ daily for more than three months) (14).

Another important issue is the assessment of osteoporotic fracture risk in these patients: Just as for the general population, the most commonly used risk calculation tool is the Fracture Risk Assessment Tool (FRAX), which was developed by the World Health Organization (WHO) using cohort data from different countries, and is available on the website: www.shef.ac.uk/FRAX/tool.jsp. This application allows the user to calculate the risk of overall fracture and hip fracture in 10 years, based on estimates for several risk factors, including the consumption of 3 or more daily units of alcohol (one unit being equivalent to 8-10 $\mathrm{g}$ of alcohol) and chronic liver disease as a cause of secondary osteoporosis (66). The advantages of FRAX include the possibility of using it without access to actual BMD values, which allows the user to estimate the risk of fracture before densitometry results become available (67). As regards its limitations, FRAX uses only the BMD of the femoral neck and does not take into account other risk factors, such as frequent falls. In addition, there are no specific multicentric studies available on the use of FRAX in populations with CLD.

The definitive diagnosis of osteoporosis in ALD is made after a bone densitometry (dual energy X-ray absorptiometry, DEXA), which is considered the gold standard for the measurement of bone density. According to the criteria of the WHO established in 1994, BMD is classified into three categories based on the T-score (standard deviation from mean BMD in young adults): Normal BMD if the T-score is greater than or equal to -1 , osteopenia if the T-score lies between -1 and -2.5 , and osteoporosis if the T-score is equal to or less than -2.5 (68). Chronic alcoholism, the presence of any risk factors for osteoporosis in a patient with ALD, or the existence of chronic cholestasis, liver cirrhosis or previous fragility fractures are indications for a DEXA scan of the lumbar spine and hip (36). Postmenopausal women with alcoholic liver disease and the presence of additional risk factors, or candidates for orthotopic liver transplantation (OLT), should also undergo a DEXA scan (53).

In patients with a high volume of ascites, a lumbar DEXA scan may show falsely decreased BMD results, as was seen in a study of 25 patients with advanced cirrhosis (24\% of alcoholic origin) who underwent a DEXA scan both before and after an evacuating paracentesis: A $7 \%$ increase in lumbar BMD was observed post-evacuation in individuals with paracentesis of more than four litres, vs. $1.5 \%$ among those with a lower volume evacuated $(\mathrm{p}<0.001)$. This was associated with a change in the pre- 
vious diagnosis of osteoporosis or osteopenia in $12 \%$ of cases, which suggests that densitometry should be carried out after paracentesis, or on alternative locations, such as the forearm (69).

Alcohol consumption is also a risk factor for the development of bone fractures $(57,70,71)$. Thirty per cent of alcoholic men with a history of more than 20 years of alcohol consumption present with vertebral fractures, although in most cases, these are asymptomatic (72). Several authors recommend performing a plain lateral X-ray of the thoracic and lumbar spine in patients with CLD to search for vertebral fractures $(36,53,65)$. The presence of radiological fractures, along with compatible densitometric criteria, allows for a diagnosis of severe osteoporosis, which in turn constitutes an indication for specific treatment to prevent future fragility fractures (36). Available studies on the prevalence of vertebral fractures in patients with CLD are scarce; these are estimated to be present in 23-36\% of cases of alcoholic cirrhosis awaiting OLT $(28,73)$. Furthermore, the estimated incidence of vertebral fractures is $30 \%$ in the first 6-12 months following a liver transplant, which is why an X-ray of the axial skeleton is recommended in the pre-transplant evaluation, to be repeated after the OLT if the patient reports loss of height or severe back pain (74). A higher incidence of post-transplant fractures has also been observed among subjects who previously had radiological fractures, which would reinforce the importance of implementing preventative measures and treatment in these patients $(65,75)$.

Laboratory analyses recommended in patients with ALD and osteoporosis include calcium, phosphorus, 25-hydroxyvitamin D and parathyroid hormone (PTH) levels, and thyroid and gonadal function tests (oestradiol, FSH and LH in women; free testosterone and testosterone/ SHBG -sex hormone-binding globulin-ratio in men) (74). There is a lack of conclusive evidence regarding the use of bone turnover markers in analytical studies of patients with ALD and suspected hepatic osteodystrophy: Both resorption markers (beta-crosslaps or carboxyl-terminal telopeptide of type I collagen) and bone formation markers (osteocalcin and total alkaline phosphatase) may be influenced by the degree of liver fibrosis and, although they might be useful in the assessment of response to antiresorptive therapy, there are no studies on their utility in ALD and their relation to BMD loss and the risk of fracture $(14,74,75)$.

\section{TREATMENT}

Available evidence on the treatment of osteopenia and osteoporosis in patients with CLD is largely based on the results and recommendations from studies and guidelines on postmenopausal osteoporosis, and on small series of patients with mixed aetiology CLD. Controlled clinical trials are lacking, and there are no specific studies on the treatment of osteoporosis in patients with ALD
$(14,49,53,74)$. This is the reason why most treatment recommendations for osteoporosis in chronic liver disease tend to be extended to ALD.

The treatment of osteodystrophy in ALD will encompass a number of general measures, applicable regardless of the level of bone involvement, and a specific drug treatment, the use of which will depend on the degree of BMD loss and the coexistence of other risk factors, such as hypogonadism $(14,74)$. Moreover, it will be necessary to consider the existence of cirrhosis and uncommon clinical scenarios, such as the treatment of osteoporosis in men or premenopausal women.

\section{General treatment measures}

Any factors that contribute to BMD loss must be identified. In the case of active alcohol consumption, the necessary measures must be taken to reach its withdrawal. In patients with a history of alcoholism, abstinence can increase serum levels of vitamin D and markers of bone formation such as osteocalcin, and may also stop bone loss, thus preventing the progression of osteopenia (31). The reversibility of the toxic effects of ethanol on bone was demonstrated in a study conducted in 53 alcoholic patients without cirrhosis who underwent rehabilitation treatment for 8 weeks: A significant increase in serum OC was observed following the alcohol withdrawal period $(21.47$ $\mathrm{g} / \mathrm{L}$ at baseline vs. $25.54 \mathrm{~g} / \mathrm{L}$ at 8 weeks, $\mathrm{p}<0.001)$, with no detectable changes in serum beta-crosslaps (33). The drugs commonly used to treat alcohol dependence have no significant adverse effects on bone metabolism, but disulfiram, naltrexone and nalmefene are contraindicated in advanced liver failure due to their hepatotoxicity (76).

Smoking cessation should be encouraged and, if glucocorticoid treatment is required for other reasons, only the minimum effective dose of the drug should be used. Moderate physical exercise is recommended, preferably activities that strengthen the lower back muscles (65). Possible nutritional deficiencies in alcoholic and CLD patients should be evaluated and corrected by dietary measures and/or supplements, given the high frequency of anorexia and malnutrition in these individuals $(77,78)$.

Supplementation with calcium and vitamin D in CLD has been studied predominantly in the context of chronic cholestatic disease. In a study of 25 women with PBC, 19 of them postmenopausal, treatment with calcitonin or placebo and daily supplements of $1 \mathrm{~g}$ of calcium increased BMD in both groups (79). In contrast, in another study of 203 patients with PBC, 96 were randomised to receive calcium without differences in BMD being observed at the lumbar level after 12 months of treatment (80).

The administration of vitamin D in patients with $\mathrm{PBC}$ did not appear to prevent the progression of osteopenia secondary to chronic cholestasis, as was observed in two small one-year prospective treatment studies $(81,82)$. In 
contrast, a study conducted in 18 men with alcoholic cirrhosis showed that patients treated with vitamin D2 $(50,000$ IU, 2-3 times/week) or 25-hydroxy-vitamin D (20-50 mg/ day) for an average of 11 months exhibited significantly improved lumbar mineral density (50). Therefore, although there are no data confirming its efficacy against bone loss, calcium and vitamin D supplementation is recommended in patients with CLD at daily doses of 1,000-1,500 mg and $800 \mathrm{IU}$, respectively -degrees of recommendation D (74) and C (14).

\section{Specific pharmacological treatment}

\section{Hormone therapy. Treatment of hypogonadism}

Hormone replacement therapy with oestrogen is effective in the prevention and treatment of postmenopausal osteoporosis and the prevention of fractures. Available evidence on the efficacy and safety of hormonal treatment in patients with CLD is scarce, and no studies have been conducted specifically in patients with ALD.

As a result of its antiresorptive effect on bone, transdermal treatment with oestradiol and medroxyprogesterone produced an increase in BMD after periods of between 1 and 2 years in postmenopausal women with PBC and postOLT patients (83-85). Treatment of male hypogonadism with testosterone has been effective in patients with hereditary haemochromatosis. However, a careful risk-benefit assessment should be carried out before its initiation (86).

Clinical guidelines for metabolic bone disease in CLD state that the use of transdermal hormone replacement therapy, including in cases of ALD, could be considered in women with hypogonadism and early menopause (under the age of 45). Male hypogonadism is treated with testosterone, always transdermally (grade D recommendation in both cases) $(53,74)$. The recommended duration of treatment for women with hypogonadism is 5-10 years. Given the increased risk of breast cancer, longer durations must be evaluated thoroughly. Following the publication of the results of the WHI (87) and HERS (88) studies, and because other effective alternatives with fewer side effects are currently available, hormone therapy is not considered a preferred option for osteoporosis in patients with chronic liver disease $(66,75)$.

\section{Bisphosphonates}

Bisphosphonates are the antiresorptive drugs of choice for the treatment of osteoporosis, their efficacy having been demonstrated in reducing the risk of vertebral and non-vertebral fractures in postmenopausal osteoporosis and that secondary to corticosteroids (89-91).

Data on the efficacy and safety of these drugs in the treatment of osteoporosis associated with CLD are still scant and inconclusive, and are derived from a limited number of studies with few patients, most of them with chronic cholestatic disease (PBC). Their results suggest that in PBC, treatment for two years with cyclical etidronate prevents BMD loss (92), and that alendronate can significantly increase BMD in the lumbar and femoral areas, with an efficacy superior to that of cyclical etidronate (93). Favourable results have recently been published for patients with $\mathrm{PBC}$ treated with weekly doses of $70 \mathrm{mg}$ of alendronate, which appears to be better tolerated than daily dosage regimens (94). There are also studies available on the use of bisphosphonates in viral CLD, in which cyclical etidronate reduced the incidence of fractures in postmenopausal women with chronic viral hepatitis after an 8-year follow-up period (95).

Bisphosphonates can cause oesophagitis and gastroesophageal mucosal ulceration (96), with a subsequent risk of gastrointestinal bleeding, which should be considered in patients with oesophageal varices. Although such effects appear to be very rare (93), some authors recommend considering parenteral administration when varices are known to be present (57). Some retrospective studies that evaluated the parenteral administration of bisphosphonates in patients with PBC concluded that $47 \%$ of patients receiving this treatment displayed an $8.7 \%$ increase in BMD at the lumbar level vs. $0.8 \%$ in the proximal femur (97). Furthermore, the use of parenteral bisphosphonates pre-OLT may be beneficial for reducing the incidence of post-transplant fractures (98). Other studies involving pamidronate, a high antiresorptive potency parenteral bisphosphonate, showed conflicting results regarding its efficacy in preventing BMD loss and fractures in patients with CLD in the pre-and post-transplant period $(99,100)$.

Despite all the above, the specific role of bisphosphonates in the treatment of osteoporosis in liver disease is yet to be defined, given the paucity of available studies and their small sample size. Similarly, there is little evidence on the use of bisphosphonates in patients with ALD, whether cirrhotic or non-cirrhotic. For this reason, management guidelines for bisphosphonates in alcoholic liver disease should be based on general clinical practice guidelines on osteoporosis and liver disease. In this regard, the consensus document of the American Gastroenterological Association (AGA) of 2003 recommended the use of bisphosphonates in patients with CLD and a diagnosis of osteoporosis, vertebral fracture, or in individuals receiving steroid treatment for periods exceeding three months (grade D recommendation) (74). The British guidelines of 2002 on the management of osteoporosis associated with CLD recommend treatment with bisphosphonates in patients presenting with fragility fractures and in cases where T-score is less than -2.5 (grade $\mathrm{C}$ recommendation) (14). Table III summarises the recommendation grades set by different scientific societies that have published guidelines on the treatment of osteoporosis in CLD.

Some of the adverse effects of bisphosphonates described in the literature include osteonecrosis of the jaw (75) 
Table III. Grades of recommendation in the pharmacological treatment of BMD (bone mineral density) disorders in chronic liver disease

\begin{tabular}{|c|c|c|}
\hline & $\begin{array}{c}\text { AGA (2003). Grade } \\
\text { of recommendation } \\
\text { (74) }\end{array}$ & $\begin{array}{c}\text { BSG (2002). Grade } \\
\text { of recommendation } \\
\text { (14) }\end{array}$ \\
\hline $\begin{array}{l}\text { Calcium and } \\
\text { vitamin D } \\
\text { supplements }\end{array}$ & $\mathrm{D}$ & C \\
\hline Bisphosphonates & $D$ & C \\
\hline $\begin{array}{l}\text { Hormone } \\
\text { replacement } \\
\text { therapy }\end{array}$ & D & $\mathrm{C}$ \\
\hline Raloxifene & $D$ & - \\
\hline PTH & $D$ & - \\
\hline
\end{tabular}

AGA: American Gastroenterological Association; BSG: British

Society of Gastroenterology; PTH: Parathyroid hormone. Grades of recommendation: $\mathrm{A}=$ Evidence from randomised controlled trials or controlled cohort studies; B = Evidence from at least one major clinical trial with the appropriate design, with or without randomisation, from cohort or case-control studies, or properly designed meta-analysis studies; $C$ = Evidence based on clinical experience, descriptive studies or expert recommendations; $\mathrm{D}=$ Evidence not verified.

and suppression of bone turnover with the consequent risk of atypical fractures (101). There are no specific guidelines regarding the duration of treatment in patients with CLD and ALD: In general, annual densitometric tests are recommended in CLD with high risk of accelerated bone loss, as is the case in patients with severe cholestasis, on steroid therapy, and in transplanted subjects. All other cases should undergo further DEXA scans every 2 to 3 years and proceed based on the results (36).

\section{Other treatments}

Raloxifene is a selective oestrogen receptor modulator approved for the treatment and prevention of postmenopausal osteoporosis. Experience with the use of raloxifene in CLD is limited to small studies in postmenopausal women with PBC (102), and no data are available on the efficacy of this drug in ALD.

Calcitonin inhibits bone resorption, and has been used subcutaneously and intranasally to prevent postmenopausal and corticosteroid-induced osteoporosis $(103,104)$. In combination with calcium and vitamin D, it effectively reduced bone loss in a group of 36 women with osteopenia and PBC (105). In contrast, when administered to patients with severe osteopenia and PBC for six months, it was proven ineffective in preventing trabecular bone loss (79). Divergent results were also observed when using calcitonin in post-OLT patients: Intramuscular administration of 40 units per day for 1 year significantly increased vertebral BMD by $6.4 \%$ in 120 post-transplant patients (106), while in another group of 63 patients with chronic cholestatic disease in their first year post-OLT, treatment with calcitonin failed to prevent bone loss and spontaneous fractures during this period (107). Available results on the efficacy of calcitonin in CLD are mixed, and there are no specific studies on its efficacy and safety in patients with ALD.

Treatment with PTH stimulates the formation of bone tissue by activating osteoblasts. Teriparatide, a molecule made up of the first 34 amino acids of PTH, has been shown to reduce the incidence of vertebral and non-vertebral fractures in post-menopausal osteoporosis while increasing vertebral and femoral BMD $(108,109)$. However, the role of PTH as a treatment for osteopenia associated with CLD is poorly defined, because only a few experimental studies have been conducted in animal models with induced cholestasis (110). It is therefore not possible to make firm recommendations for the treatment of osteoporosis with PTH or teriparatide in patients with ALD.

\section{Orthotopic liver transplantation}

The majority of post-OLT patients suffer a loss of BMD in the first 3-6 months after transplantation $(111,112)$. The probability of bone fracture in this period ranges between $6 \%$ and $65 \%$ (113), with the highest incidence in the first 2 years and in the spine $(75,114)$.

Factors that predispose to bone loss after OLT include high-dose steroid and immunosuppressive therapy, nutritional changes and perioperative immobilisation (115). However, and despite the initial loss of BMD, bone loss has been observed to improve in the medium and long term. That is why OLT is considered to be the most effective treatment for osteoporosis in patients with CLD.

Various bisphosphonates such as alendronate, risedronate, zoledronic acid, and pamidronate, associated with calcium and vitamin D in some cases, have been the subject of many studies on the treatment and prevention of post-OLT osteoporosis. Weekly doses of alendronate have been shown to significantly increase BMD and prevent post-OLT bone loss, although without significant effects on the rate of bone fractures $(116,117)$. Pamidronate, when administered 1 and 12 weeks after transplantation, increased BMD in the lumbar spine (118), and zoledronic acid (a parenteral bisphosphonate) yielded favourable results on total lumbar, femoral neck and hip bone mass in the context of a treatment regimen after 1 week, and at 1, 3, 6 and 9 months post-OLT, though with notable side effects, such as secondary hyperparathyroidism and hypocalcaemia post-infusion (119). It is worth noting that both pamidronate and zoledronic acid exhibited no significant effects on the incidence of post-transplant fractures in initial investigations, although subsequent studies have reported significant reductions in their incidence when higher doses of zoledronate were used during the first 12 months after OLT (120). More recent studies have assessed the effectiveness of pamidronate when adminis- 
tered monthly together with calcium and vitamin D for the treatment of post-transplant osteopenia and its impact on the incidence of bone fractures. A significant increase in lumbar spine and femoral neck BMD was reported, as well as a decrease in the post-transplant fracture rate to $5.4 \%$ (111). To date, no tests have been designed to specifically assess the effectiveness of treatment with bisphosphonates in patients with alcoholic cirrhosis having undergone OLT, and their ability to prevent bone loss and reduce fracture rates.

\section{AREAS OF UNCERTAINTY. CLINICAL GUIDELINES}

There is a great deal of variability in the incidence of BMD abnormalities across the different series published, which tend to group chronic liver disease of different aetiologies into groups with small sample sizes. The multifactorial nature of bone loss in CLD as a whole and ALD in particular means that its pathogenic mechanisms are still poorly understood. Further prospective, multicentre studies should therefore be conducted in homogeneous populations in terms of aetiology and stage of CLD. This aspect is particularly relevant in the case of ALD, given the wide spectrum of liver damage caused by alcohol and that, according to the results described in other studies, the extent of bone disease is higher in the advanced stages of alcoholic liver failure.

There are no specific algorithms for BMD alterations in patients with ALD. Based on the recommendations of the guidelines published on the subject for CLD, we propose an orientative algorythm adapted to patients with alcoholic liver disease (Fig. 1). As regards the treatment of osteoporosis in the clinical context of ALD, current evidence was not drawn from randomised controlled trials, but from the results of small studies on groups of patients with CLD of different aetiologies, predominantly chronic cholestatic disease and groups of patients with advanced cirrhosis awaiting OLT.

Some clinical practice guidelines have been published on the management of osteopenia and osteoporosis in CLD: The consensus of the working group of the British Association for the Study of the Liver and the British Liver Trust was published in 2002 (13), and the technical review of the AGA on osteoporosis in liver disease in 2003 (73). Both documents include the main guidelines and recommendations for the diagnosis and treatment of hepatic osteodystrophy. The systematic review carried out concluded that current scientific evidence in this field is still very scarce, both in terms of the aetiopathogenic aspects and clinical management of osteoporosis secondary to CLD. There are no special recommendations for the different aetiologies of CLD, and hence, there are no specific treatment regimens specified for patients with ALD. The recommendations reflected in this review (Fig. 1) are mostly consistent with those listed in the clinical guidelines mentioned above.

\section{CONCLUSIONS}

BMD loss is a common complication of CLD as a whole, and also of ALD. Alcohol consumption and secondary liver disease are predisposing factors for BMD loss. The aetiopathogenesis of osteoporosis in ALD is multifactorial, and impaired bone formation appears to be the main mechanism involved in the onset of osteopenia as a result of direct alcohol toxicity on bone, associated macro- and micronutrient disturbances, endocrine-metabolic disorders secondary to alcoholism and CLD, and the release of various cytokines with harmful effects on bone mass.

Bone densitometry is critical for the diagnosis of osteoporosis, and analytical studies are also recommended to rule out concomitant disturbances in gonadal function and vitamin D levels in all patients with ALD. The main indications for conducting a BMD study in patients with ALD are: Alcoholic cirrhosis, the presence of significant cholestasis, and a history of bone fragility fracture. It is also important to perform densitometry in patients who are candidates for OLT, as low BMD and the existence of previous fractures both increase the risk of bone loss in the post-transplant period. Lastly, patients with ALD and other risk factors for osteoporosis should also undergo an assessment of BMD by means of a DEXA scan.

Alcohol cessation and abstinence are essential for the prevention and treatment of osteoporosis in ALD patients, having been proven to be able to stop the progression of osteopenia. Associated nutritional deficiencies must also be corrected, and supplementation with calcium and vitamin $\mathrm{D}$ is recommended. There are no specific guidelines for the pharmacological treatment of osteoporosis in ALD. Bisphosphonates, which have a good safety profile and have proven effective in increasing BMD in chronic cholestatic disease and post-transplant patients, are currently the main choice for specific antiresorptive therapy.

Practice guidelines on BMD and chronic liver disease include recommendations for its diagnosis and treatment, but do not include evidence drawn from the series and studies conducted on the subject that have been published in recent years. It would be beneficial to have access to randomised, prospective, multicentre studies conducted on homogeneous groups with chronic alcoholic liver disease in its various stages. The performance of studies on treatment with bisphosphonates and new antiosteoporotic agents in patients with ALD would be useful to improve the clinical management of osteoporosis in this population. Moreover, it is also necessary to understand specific BMD alterations in ALD patients in the pre- and post-transplant stages, and the usefulness of antiresorptive drugs in fracture prevention and in the treatment of osteoporosis in these patients. 


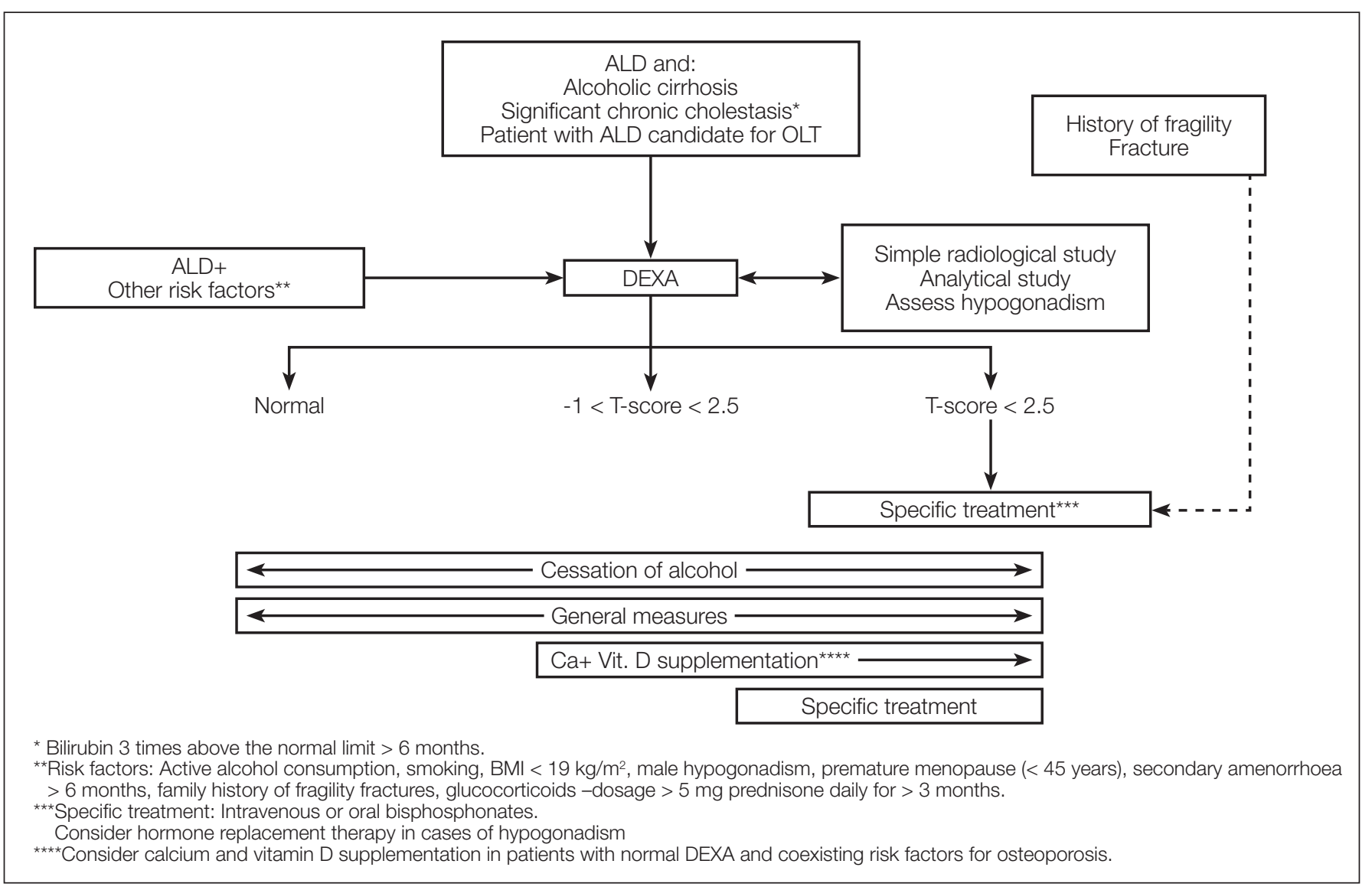

Fig. 1. Diagnosis and treatment of BMD disorders in patients with alcoholic liver disease. Adapted from: Collier J, et al. (14). ALD: Alcoholic liver disease; OLT: Orthotopic liver transplantation; DEXA: Dual X-ray absorptiometry (bone densitometry).

\section{REFERENCES}

1. Alter MJ. Hepatitis C virus infection in the United States. J Hepatol 1999;31:88-91.

2. Sanchez AJ, Aranda-Michel J. Liver disease and osteoporosis. Nutr Clin Pract 2006;21:273-8.

3. Gasser RW. Cholestasis and metabolic bone disease - a clinical review. Wien Med Wochenschr 2008;158:553-7.

4. Schiefke I, Fach A, Wiedmann M, Aretin AV, Schenker E, Borte G, et al. Reduced bone mineral density and altered bone turnover markers in patients with non-cirrhotic chronic hepatitis B or C infection. World J Gastroenterol 2005;11:1843-7.

5. Moon SS, Lee YS, Kim SW. Association of nonalcoholic fatty liver disease with low bone mass in postmenopausal women. Endocrine 2012;42:423-9.

6. González-Reimers E, Alvisa-Negrín J, Santolaria-Fernandez F, RosVilamajó R, Martín-González MC, Hernández-Betancor I, et al. Prognosis of osteopenia in chronic alcoholics. Alcohol 2011;45:227-38.

7. Guggenbuhl P, Fergelot P, Doyard M, Libouban H, Roth MP, Gallois $\mathrm{Y}$, et al. Bone status in a mouse model of genetic hemochromatosis. Osteoporos Int 2011;22:2313-9.

8. Rueda Adel C, Grande NC, Fernández EA, Enríquez de Salamanca R, Sala LA, Jiménez MJ. Mutations in HFE and TFR2 genes in a Spanish patient with hemochromatosis. Rev Esp Enferm Dig 2011;103:379-82.

9. Paula H, Asrani SK, Boetticher NC, Pedersen R, Shah VH, Kim WR. Alcoholic liver disease-related mortality in the United States: 19802003. Am J Gastroenterol 2010;105:1782-7.

10. O’Shea RS, Dasarathy S, McCullough AJ; Practice Guideline Committee of the American Association for the Study of Liver Diseases,
Practice Parameters Committee of the American College of Gastroenterology. Alcoholic liver disease. Hepatology 2010;51:307-28.

11. Koff RS, Dienstag JL. Extrahepatic manifestations of hepatitis C and the association with alcoholic liver disease. Semin Liver Dis 1995; 15:101-9.

12. Poor G, Atkinson EJ, O’Fallon WM, Melton LJ 3rd. Predictors of hip fractures in the elderly. J Bone Miner Res 1995;10:1990-7.

13. Diamond T, Stiel D, Lunzer M, Wilkinson M, Posen S. Ethanol reduces bone formation and may cause osteoporosis. Am J Med 1989;86:282-8.

14. Collier JD, Ninkovic M, Compston JE. Guidelines on the management of osteoporosis associated with chronic liver disease. Gut 2002;50(Supl. 1):i1-9.

15. Spencer H, Rubio N, Rubio E, Indreika M, Seitam A. Chronic alcoholism. Frequently overlooked cause of osteoporosis in men. Am J Med 1986;80:393-7.

16. González-Calvin JL, García-Sánchez A, Bellot V, Muñoz-Torres M, Raya-Álvarez E, Salvatierra-Ríos D. Mineral metabolism, osteoblastic function and bone mass in chronic alcoholism. Alcohol Alcohol 1993;28:571-9.

17. Laitinen K, Karkkainen M, Lalla M, Lamberg-Allardt C, Tunninen R, Tahtela R, et al. Is alcohol an osteoporosis-inducing agent for young and middle-age women? Metabolism 1993;42:875-81.

18. Odvina CV, Safi I, Wojtowicz CH, Barengolts EI, Lathon P, Skapars A, et al. Effect of heavy alcohol intake in the absence of liver disease on bone mass in black and white men. J Clin Endocrinol 1995;80:2499-503.

19. Kim MJ, Shim MS, Kim MK, Lee Y, Shin YG, Chung CH, et al. Effect of chronic alcohol ingestion on bone mineral density in males without liver cirrhosis. Korean J Inter Med 2003;18:174-80.

20. Malik P, Gasser RW, Kemmler G, Moncayo R, Finkenstedt G, Kurz $\mathrm{M}$, et al. Low bone mineral density and impaired bone metabolism 
in young alcoholic patients without liver cirrhosis: a cross-sectional study. Alcohol Clin Exp Res 2009;33:375-81.

21. Crawford BAL, Kam C, Donaghy AJ, McCaughan GW. The heterogeneity of bone disease in cirrhosis: A multivariate analysis. Osteoporos Int 2003; 14:987-94

22. Carey E, Balan. Metabolic bone disease in patients with liver disease. Curr Gastroenterol Rep 2003;5:71-7.

23. Sokhi RP, Anantharaju A, Kondaveeti R, Creech SD, Islam KK, van Thiel D. Bone mineral density among cirrhotic patients awaiting liver transplantation. Liver Transpl 2004;10:648-53.

24. George J, Ganesh HK, Acharya S, Bandgar TR, Shivane V, Karvat A, et al. Bone mineral density and disorders of mineral metabolism in chronic liver disease. World J Gastroenterol 2009;15:3516-22.

25. Loria I, Albanese C, Giusto M, Galtieri PA, Giannelli V, Lucidi C, et al. Bone disorders in patients with chronic liver disease awaiting liver transplantation. Transplant Proc 2010;42:1191-3.

26. Mitchell R, McDermid J, Ma MM, Chik CL. MELD score, insulinlike growth factor 1 and cytokines on bone density in end-stage liver disease. World J Hepatol 2011;3:157-63.

27. Mahmoudi A, Sellier N, Reboul-Marty J, Chalès G, Lalatonne Y, Bourcier V, et al. Bone mineral density assessed by dual-energy $\mathrm{X}$-ray absorptiometry in patients with viral or alcoholic compensated cirrhosis. A prospective study. Clin Res Hepatol Gastroenterol 2011;35:731-7.

28. Wibaux C, Legroux-Gerot I, Dharancy S, Boleslawski E, Declerck $\mathrm{N}$, Canva V, et al. Assessing bone status in patients awaiting liver transplantation. Joint Bone Spine 2011;78:387-91.

29. Choudhary NS, Tomar M, Chawla YK, Bhadada SK, Khandelwal N, Dhiman RK, et al. Hepatic osteodystrophy is common in patients with noncholestatic liver disease. Dig Dis Sci 2011;56:3323-7.

30. Alcalde-Vargas A, Pascasio-Acevedo JM, Gutiérrez-Domingo I, García-Jiménez R, Sousa-Martín JM, Ferrer-Ríos MT, et al. Prevalence and characteristics of bone disease in cirrhotic patients under evaluation for liver transplantation. Transplant Proc 2012;44:1496-8.

31. Alvisa-Negrín J, González-Reimers E, Santolaria-Fernández F, GarcíaValdecasas-Campelo E, Alemán-Valls MR, Pelazas-González R, et al. Osteopenia in alcoholics: Effect of alcohol abstinence. Alcohol Alcohol 2009;44:468-75.

32. Gonzalez-Reimers E, Alvisa-Negrín J, Santolaria-Fernández F, MartínGonzález MC, Hernández-Betancor I, Fernández-Rodríguez CM, et al. Vitamin D and nutritional status are related to bone fractures in alcoholics. Alcohol Alcohol 2011;46:148-55.

33. Malik P, Gasser RW, Moncayo R, Kemmler G, Fleischhaker WW. Markers of bone resorption and formation during abstinence in male alcoholic patients. Alcohol Clin Exp Res 2012;36:2059-64.

34. Guañabens N, Pares A, Marinosos L. Factors influencing the development of metabolic bone disease in primary biliary cirrhosis. Am J Gastroenterol 1990;85:1356-62.

35. Guichelaar MM, Malinchoc M, Sibonga JD, Clarke BL, Hay JE. Bone histomorphometric changes after liver transplantation for chronic cholestatic liver disease. J Bone Miner Res 2003;18:2190-9.

36. Guañabens N, Parés A. Osteoporosis in liver cirrhosis. Gastroenterol Hepatol 2012;35:411-20.

37. Cuthbert JA, Pak CY, Zerwekh JE, Glass KD, Combes B. Bone disease in primary biliary cirrhosis: Increased bone resorption and turnover in the absence of osteoporosis or osteomalacia. Hepatology 1984;4:1-8.

38. Hodgson SF, Dickson ER, Eastell R, Eriksen EF, Bryant SC, Riggs BL. Rates of cancellous bone remodelling and turnover in osteopenia associated with primary biliary cirrhosis. Bone 1993;14:819-27.

39. Ruiz-Gaspà S, Martínez-Ferrer A, Guañabens N, Dubreuil M, Peris P, Enjuanes A, et al. Effects of bilirubin and sera from jaundiced patients on osteoblasts: Contribution to the development of osteoporosis in liver diseases. Hepatology 2011;54:2104-13.

40. Dai J, Lin D, Zhang J, Habib P, Smith P, Murtha J, et al. Chronic alcohol ingestion induces osteoclastogenesis and bone loss through IL-6 in mice. J Clin Invest 2000;106:887-95.

41. Turner RT. Skeletal response to alcohol. Alcohol Clin Exp Res 2000;24:1693-701

42. Wezeman FH, Emanuele MA, Moskal SF, Steiner J, Lapaglia N. Alendronate administration and skeletal response during chronic alcohol intake in the adolescent male rat. J Bon Miner Res 2000;15:2033-41.
43. Peris P, Parès A, Guañabens N, Pons F, Martínez de Osaba MJ, Caballeria $\mathrm{J}$, et al. Reduced spinal and femoral bone mass and deranged bone mineral metabolism in chronic alcoholics. Alcohol Alcohol 1992;27:619-25.

44. González-Reimers E, Martín-González C, De la Vega-Prieto MJ, Pelazas-González R, Fernández-Rodríguez C, López-Prieto J, et al. Serum sclerostin in alcoholics: A pilot study. Alcohol Alcohol 2013;48:278-82.

45. Molina-Pérez M, González-Reimers E, Santolaria-Fernandez F, Martínez-Riera A, Rodríguez-Moreno F, Rodríguez-Rodríguez E, et al. Relative and combined effects of ethanol and protein deficiency on bone hsitology and mineral metabolism. Alcohol 2000;20:1-8.

46. Fitzpatrick LA. Secondary causes of osteoporosis. Mayo Clin Proc 2002;77:453-68.

47. de los Santos-Moreno A, Romero-Cores P, Navarro F, Girón-González JA. Malabsorption syndrome (II). Celiac disease. Lactose intolerance. Bacterial overgrowth. Medicine (Barc) 2012;11:206-13.

48. Reed BY, Zerwekh JE, Sakhaee K, Breslau NA, Gottschalk F, Pak CY. Serum IGF- 1 is low and correlated with osteoblastic surface in idiopathic osteoporosis. J Bone Miner Res 1995;10:1218-24.

49. López-Larramona G, Lucendo AJ, González-Castillo S, Tenias JM Hepatic osteodystrophy: An important matter for consideration in chronic liver disease. World J Hepatol 2011;3:300-7.

50. Mobarhan SA, Russell RM, Recker RR, Posner DB, Iber FL, et al. Metabolic bone disease in alcoholic cirrhosis: A comparison of the effect of vitamin D2, 25-hydroxyvitamin D or supportive treatment. Hepatology 1984;4:266-73.

51. Masuda S, Okano T, Osawa K, Shinjo M, Suematsu T, Kobayashi T. Concentrations of vitamin $\mathrm{D}$ binding protein and vitamin $\mathrm{D}$ metabolites in plasma of patients with liver cirrhosis. J Nutr Sci Vitaminol (Tokyo) 1989;35:225-34.

52. Jorge-Hernández JA, González-Reimers E, Torres-Ramírez A, Santolaria-Fernández F, González-García C, et al. Bone changes in alcoholic liver cirrhosis. A histomorphometrical analysis of 52 cases. Dig Dis Sci 1988;33:1089-95.

53. Hay JE, Guichelaar MMJ. Evaluation and management of osteoporosis in liver disease. Clin Liver Dis 2005;9:747-66.

54. Pares A, Guañabens N, Rodés J. Gene polymorphisms as predictors of decreased bone mineral density and osteoporosis in primary biliary cirrhosis. Eur J Gastroenterol Hepatol 2005;17:311-15.

55. Ruiz-Gaspà S, Guañabens N, Enjuanes A, Peris $P$, Martinez-Ferrer A, de Osaba MJ. Lithocolic acid downregulates vitamin D effects in human osteoblasts. Eur J Clin Invest 2010;40:25-34.

56. Shiomi S, Nishiguchi S, Kubo S, Tamori A, Habu D, Takeda T, et al. Vitamin K2 (menatetrenone) for bone loss in patients with cirrhosis of the liver. Am J Gastroenterol 2002;97:978-81.

57. Hay JE. Osteoporosis in liver diseases and after liver transplantation. J Hepatol 2003;38:856-65.

58. Diamond T, Stiel D, Lunzer M, Wilkinson M, Roche J, Posen S. Osteoporosis and skeletal fractures in chronic liver disease. Gut 1990;31:82-7.

59. Moschen AR, Kaser A, Stadlmann S, Millonig G, Kaser S, Mühlechner $\mathrm{P}$, et al. The RANKL/OPG system and bone mineral density in patients with chronic liver disease. J Hepatol 2005;43:973-83.

60. Gonzalez-Calvin JL, Mundi JL, Casado-Caballero FJ, Abadia AC, Martin-Ibañez JJ. Bone mineral density and serum levels of soluble tumor necrosis factors, estradiol, and osteoprotegerin in postmenopausal women with cirrhosis after viral hepatitis. J Clin Metab 2009;94:4844-50.

61. Diez Ruiz A, Santos Perez JL, Lopez Martinez G, Gonzalez-Calvin JL, Gil Extremera B, Gutierrez Gea F. Tumor necrosis factor, interleukin- 1 and interleukin-6 in alcoholic cirrhosis. Alcohol Alcohol 1993;28:319-23.

62. Boyle WJ, Simonet WS, Lacey DL. Osteoclast differentiation and activation. Nature 2003;423:337-42.

63. Bu R, Borysenko CW, Li Y, Cao L, Sabokbar A, Blair HC. Expression and function of TNF-family proteins and receptors in human osteoblasts. Bone 2003;33:760-70.

64. Garcia-Valdecasas-Campelo E, Gonzalez-Reimers E, Santolaria-Fernandez F, De la Vega-Prieto MJ, Milena-Abril A, Sanchez-Perez MJ, et al. Serum osteoprotegerin and RANKL levels in chronic alcoholic liver disease. Alcohol Alcohol 2006;41:261-6.

65. Parés A, Guañabens N. Treatment of bone disorders in liver disease. J Hepatol 2006;45:445-53. 
66. del Pino Montes J. Tratamiento de la osteopenia y la osteoporosis. Medicine (Barc) 2011;10:6221-9.

67. Kanis JA, Oden A, Johansson H, Borgstrom F, Strom O, McCloskey E. FRAX and its applications to clinical practice. Bone 2009;44:734-43.

68. WHO Assessment of fracture risk and its application to screening for postmenopausal osteoporosis. Report of a WHO Study Group. World Health Organ Tech Rep Ser 1994;843:1-129.

69. Guañabens N, Monegal A, Muxi A, Martínez-Ferrer A, Reyes R, Caballeria J, et al. Patients with cirrhosis and ascites have false values of bone density. Implications for the diagnosis of osteoporosis. Osteoporos Int 2012;23:1481-7.

70. Wosje KS, Kalkwarf HJ. Bone density in relation to alcohol intake among men and women in the United States. Osteoporos Int 2007;18:391-400.

71. Gonzalez-Reimers E, Garcia-Valdecasas-Campelo E, Santolaria-Fernandez F, Milena-Abril A, Rodriguez-Rodriguez E, Martinez-Riera A, et al. Rib fractures in chronic alcoholic men: Relationship with feeding habits, social problems, bone alterations, and liver dysfunction. Alcohol 2005;37:113-7.

72. Peris P, Guanabens N, Parès A, Pons F, Del Río L, Monegal A, et al. Vertebral fractures and osteopenia in chronic alcoholic patients. Calcif Tissue Int 1995;57:111-4.

73. Carey EJ, Balan V, Kremers WK, Hay JE. Osteopenia and osteoporosis in patients with end-stage liver disease caused by hepatitis $\mathrm{C}$ and alcoholic liver disease: Not just a cholestatic problem. Liver Transpl 2003;9:1166-73.

74. Leslie WD, Bernstein CN, Leboff MS, American Gastroenterological Association Clinical Practice Commitee. AGA Technical review on osteoporosis in hepatic disorders. Gastroenterology 2003;125:941-66.

75. Collier J. Bone disorders in chronic liver disease. Hepatology 2007;46:1271-8.

76. Ávila-Escribano JJ, Marcos-Martín M, Pastor-Encinas I, Laso-Guzmán FJ. Treatment of alcohol dependence. Medicine (Barc) 2012;11:1412-20.

77. Kondrup J. Nutrition in end stage liver disease. Best Pract Res Clin Gastroenterol 2006;20:547-60.

78. Tsiaousi ET, Hatzitolios AI, Trygonis SK, Savopoulos CG. Malnutrition in end stage liver disease: Recommendations and nutritional support. J Gastroenterol Hepatol 2008;23:527-33.

79. Camisasca M, Crosignani A, Baltezzati PM, Albisetti W, Grandinetti G, Pietrogrande L, et al. Parenteral calcitonin for metabolic bone disease associated with primary biliary cirrhosis. Hepatology 1994;20:633-7.

80. Crippin JS, Jorgensen RA, Dickson ER, Lindor KD. Hepatic osteodystrophy in primary biliary cirrhosis: Effects of medical treatment. Am J Gastroenterol 1994;89:47-50.

81. Herlong H, Recker R. Bone disease in primary biliary cirrhosis: Histologic features and response to 25-hydroxyvitamin D. Gastroenterology 1982;83:103-8.

82. Matloff DS, Kaplan, M, Neer RM, Goldberg MJ, Bitman W, Wolfe HJ. Osteoporosis in primary biliary cirrhosis: effects of 25-hydroxyvitamin D3 treatment. Gastroenterology 1982;83:97-102.

83. Pereira SP, O’Donohue J, Moniz C, Phillips MG, Abraha H, BuxtonThomas M, et al. Transdermal hormone replacement therapy improves vertebral bone density in primary biliary cirrhosis. Aliment Pharmacol Ther 2004;19:563-70.

84. Ormarsdóttir S, Mallmin H, Naessén T, Petrén-Mallmin M, Broomé U, Hultcrantz R, et al. An open, randomized, controlled study of transdermal hormone replacement therapy on the rate of bone loss in primary biliary cirrhosis. J Intern Med 2004;256:63-9.

85. Isoniemi H, Appelberg J, Nilsson CG, Makela P, Risteli J, Hockerstedt $K$. Transdermal oestrogen therapy protects postmenopausal liver transplant women from osteoporosis. A 2-year follow-up study. J Hepatol 2001;34:299-305

86. Diamond T, Stiel D, Posen S. Effects of testosterone and venesection on spinal and peripheral bone mineral in six hypogonadal men with hemochromatosis. J Bone Miner Res 1991;6:39-43.

87. Rossouw JE, Anderson GL, Prentice RL, LaCroix AZ, Kooperberg C, Stefanick ML, et al. Risks and benefits of estrogen plus progestin in healthy postmenopausal women: principal results from the Women's Health Initiative randomized controlled trial. JAMA 2002;288:321-33.

88. American College of Obstetricians and Gynecologists. Statement on results of the HERS II trial on hormone replacement therapy. Ginecol Obstet Mex 2002;70:406-8.
89. Cranney A, Wells G, Willan A, Griffith L, Zytaruk N, Robinson V, et al. Meta-analysis of alendronate for the treatment of postmenopausal women. Endocr Rev 2002;23:508-16.

90. Adachi J, Bensen W, Brown J, Hanley D, Hodsman A, Josse R, et al. Intermittent etidronate therapy to prevent corticosteroid-induced osteoporosis. N Engl J Med 1997;337:382-7.

91. Watts NS, Harris ST, Genant HK, Wasnich RD, Miller PD, Jackson $\mathrm{RD}$, et al. Intermittent cyclical etidronate treatment of postmenopausal osteoporosis. N Eng J Med 1990;323:73-9.

92. Wolfhagen FH, van Buuren HR, den Ouden JW, Hop WC, van Leeuwen JP, Schalm SW, et al. Cyclical etidronate in the prevention of bone loss in corticosteroid-treated primary biliary cirrhosis. A prospective, controlled pilot study. J Hepatol 1997;26:325-30.

93. Guañabens N, Pares A, Ros I, Alvarez L, Pons F, Caballeria L, et al Alendronate is more effective than etidronate for increasing bone mass in osteopenic patients with primary biliary cirrhosis. Am J Gastroenterol 2003;98:2268-74.

94. Zein CO, Jorgensen RA, Clarke B, Wenger D, Keach JC, Angulo $\mathrm{P}$, et al. Alendronate improves bone mineral density in primary biliary cirrhosis: A randomized placebo-controlled trial. Hepatology 2005;42:762-71.

95. Arase Y, Suzuki F, Suzuki Y, Akuta N, Kobayashi M, Kawamura $\mathrm{Y}$, et al. Prolonged-efficacy of bisphosphonate in postmenopausal women with osteoporosis and chronic liver disease. J Med Virol 2008;80:1302-7

96. Aibar Arregui MA, de Escalante Yangüela B, Muñoz Villalengua M, Garcés Horna V. Esophageal stenosis caused by alendronate. Rev Esp Enferm Dig 2011;103:338-9.

97. Treeprasertsuk S, Silveira MG, Petz JL, Lindor KD. Parenteral bisphosphonates for osteoporosis in patients with primary biliary cirrhosis. Am J Ther 2011;18: 375-81.

98. Reeves HL, Francis RM, Manas DM, Hudson M, Day CP. Intravenous bisphosphonate prevents symptomatic osteoprotic vertebral collapse in patients after liver transplantation. Liver Transpl Surg 1998;4:404-9.

99. Monegal A, Navasa M, Suárez M, Suárez-López S, García-González F, Serrano T. Effects of intravenous pamidronate on bone loss after liver transplantation. Calcif Tissue Int 2006;78:S148.

100. Dodidou P, Bruckner T, Hosch S, Haas M, Klar E, Sauer P. Better late than never? Experience with intravenous pamidronate in patients with low bone mass or fractures following cardiac or liver transplantation. Osteoporos Int 2003;14:82-9.

101. Yadav A, Carey EJ. Osteoporosis in chronic liver disease. Nutr Clin Pract 2013;28:52-64

102. Levy C, Harnois DM, Angulo P, Jorgensen R, Lindor. Raloxifene improves bone mass in osteopenic woman with primary biliary cirrhosis: Results of a pilot study. Liver Int 2005;25:117-21.

103. Overgaard K, Hansen M, Jensen SB, Christiansen C. Effect of salcatonin given intranasally on bone mass and fracture rates in established osteoporosis: A dose-response study. BMJ 1992;305:556-61.

104. Cranney A, Tugwell P, Zytaruk N, Robinson V, Weaber B, Shea B, et al. Meta-analysis of calcitonin for the treatment of postmenopausal women. Endocr Rev 2002;23:540-51.

105. Floreani A, Zappala F, Fries W, Naccarato R, Plebani M, D’Angelo A, et al. A 3-year pilot study with 1,25-dihydroxyvitamin D, calcium and calcitonin for severe osteodystrophy in primary biliary cirrhosis. J Clin Gatroenterol 1997;24:239-44.

106. Valero MA, Loinaz C, Larrodera L. Calcitonin and bisphosphonates treatment in bone loss after liver transplantation. Calcif Tissue Int 1995;57:15-9.

107. Hay JE, Malinchoc M, Dickson ER. A controlled trial of calcitonin therapy for the prevention of post-liver transplantation atraumatic fractures in patients with primary biliary cirrhosis and primary sclerosing cholangitis. J Hepatol 2001;34:292-8.

108. Neer RM, Arnaud CD, Zanchetta JR, Prince R, Gaich GA, Reginster GY, et al. Effect of parathyroid hormone (1-34) on fractures and bone mineral density in postmenopausal women with osteoporosis. N Engl J Med 2001;344:1434-41.

109. Hodsman AB, Hanley DA, Ettinger MP, Bolognese MA, Fox J, Metcalfe AJ, et al. Efficacy and safety of human parathyroid hormone (1-84) in increasing bone mineral density in postmenopausal osteoporosis. J Clin Endocrinol Metab 2003;88:5212-20. 
110. Dresner-Pollak R, Gabet Y, Steimatzky A, Hamdani G, Bab I, Ackerman $\mathrm{Z}$, et al. Human parathyroid hormone 1-34 prevents bone loss in experimental biliary cirrhosis in rats. Gastroenterology 2008;134:259-67.

111. Ninkovic M, Skingle SJ, Bearcroft PW, Bishop N, Alexander GJ, Compston JE. Incidence of vertebral fractures in the first three months after orthotopic liver transplantation. Eur J Gastroenterol Hepatol 2000;12:931-5.

112. Guichelaar MM, Schmoll J, Malinchoc M, Hay JE. Fractures and avascular necrosis before and after orthotopic liver transplantation: Longterm follow-up and predictive factors. Hepatology 2007;46:1198-207.

113. Kaemmerer D, Schmidt B, Lehmann G, Wolf G, Hommann M, Settmacher U. Monthly ibandronate for the prevention of bone loss in patients after liver transplantation. Transplant Proc 2012;44:1362-7.

114. Compston JE. Osteoporosis after liver transplantation. Liver Transpl 2003;9:321-30.

115. Cheung AM. Post-liver transplantation osteoporosis. J Hepatol 2001;34:337-8
116. Millonig G, Graziadei I, Eichler D, Pfeiffer KP, Finkenstedt G, Muehllechner $\mathrm{P}$, et al. Alendronate in combination with calcium and vitamin D prevents bone loss after orthotopic liver transplantation: A prospective single-center study. Liver Transpl 2005;11:960-6.

117. Atamaz F, Hepguler S, Akyildiz M, Karasu Z, Kilic M. Effects of alendronate on bone mineral density and bone metabolic markers in patients with liver transplantation. Osteoporos Int 2006;17:942-9.

118. Monegal A, Guañabens N, Suárez MJ, Suárez F, Clemente G, García-González M, et al. Pamidronate in the prevention of bone loss after liver transplantation: A randomized controlled trial. Transpl Int 2009;22:198-206.

119. Crawford BAL, Kam C, Pavlovic J, Byth K, Handelsman DJ, Angus $\mathrm{PW}$, et al. Zoledronic acid prevents bone loss after liver transplantation: A randomized, double-blind, placebo-controlled trial. Ann Inter Med 2006;144:239-48.

120. Bodingbauer M, Wekerle T, Pakrah B, Roschger P, Peck-Radosavljevic M, Silberhumer G, et al. Prophylactic bisphosphonate treatment prevents bone fractures after liver transplantation. Am J Transplant 2007;7:1763-9. 